\title{
Seeding of Creeping Bluegrass into Existing Golf Course Putting Greens
}

\author{
Eric D. Miltner, Gwen K. Stahnke, Geoffrey J. Rinehart, and \\ Paul A. Backman ${ }^{1}$ \\ Department of Crop and Soil Sciences, Washington State University, Puyallup \\ Research and Extension Center, 7612 Pioneer Way East, Puyallup, WA 98371
}

Additional index words. aerification, cultivation, topdressing, verticutting

\begin{abstract}
The recent release of 'True-Putt' (previously 'DW-184') creeping bluegrass [Poa annua L. f. reptans (Hauskins) T. Koyama] gives turfgrass managers a new option for seeding into annual bluegrass (Poa annua L.) greens. Because little is known about the culture and management of this newly available seeded cultivar, effective methods for seedling establishment into existing turfgrass canopies, both living and dead, were studied. Four surface cultivation treatments were compared for seedbed preparation before seeding into an existing turfgrass canopy. When seeding into dead turf, two passes with vertical mowing units were more effective than hollow-tine cultivation (HTC), solid-tine cultivation (STC), one pass with the vertical mower plus STC, and the uncultivated control during the first year. Differences were not significant during the second year, most likely because of shallower depth of the vertical mower. Plots averaged about $75 \%$ cover by 4 weeks after planting during both years, illustrating the rapid establishment potential for 'True-Putt'. After seeding into a live turf canopy, seedlings were indistinguishable from the existing turf, making it impossible to evaluate establishment success.
\end{abstract}

Annual bluegrass (Poa annua L.) is commonly found on golf course putting greens in the northern U.S., and in the Pacific Northwest it is usually the predominant species. It is often regarded as an undesirable species due to its light green color, prolific flowering that creates an uneven putting surface, and susceptibility to environmental stress (Beard, 1973). Despite this, it can become the dominant species on a putting green over time (Beard et al., 1978). Golf course superintendents then must manage annual bluegrass as a desirable turf species.

Individual annual bluegrass plants exhibit a range of growth habits from that of a true winter annual to a perennial (Christians, 1998). These biotypes have been designated as separate subspecies: P. annua L. var. annua Timm (annual type) and $P$. annua L. f. reptans (Hauskins) T. Koyama (perennial type). Recent efforts in plant improvement have focused on selection for perennial growth habit, low vertical height, high shoot density, acceptable color, and reduced flowering. 'DW- 184' was the first commercially available cultivar (White and Carson, 1999). This was renamed 'TruePutt' and marketed with the common name of creeping bluegrass. Before this release, turf managers established annual bluegrass by a variety of methods: collection of clippings during periods of seed production and spreading these over soil, anticipating that mature seed would germinate; spreading of soil cores collected during core aerification; or seeding of creeping bentgrass (Agrostis stolonifera L.) or

Received for publication 13 Aug. 2004. Accepted for publication 2 Oct. 2004. CSS Dept. Sci. Paper No. 1101-03. Research supported by the Washington Agricultural Research Center and Northwest Turfgrass Association.

${ }^{1}$ Current address: TurfAlliance, 2203 Nut Tree Loop SE, Olympia, WA 98501. other turf species, with subsequent colonization by annual bluegrass from resident seed pools. None of these methods provide for reliable, rapid establishment. The availability of creeping bluegrass seed provides an opportunity for more direct establishment methods.

In the Pacific Northwest, creeping bluegrass is primarily being used to repair partially damaged areas without complete renovation, seeding into existing thin or dead turf stands. Various procedures have been used to introduce seed into existing canopies of cool season turfgrasses. Roberts and Goss (1979) found that spiking to a depth of $6 \mathrm{~cm}$ in combination with slit seeding to a depth of $5 \mathrm{~cm}$ was most effective for seeding colonial bentgrass (A. capillaris L.) into an existing putting green. Reicher and Hardebeck (2002) evaluated overseeding of creeping bentgrass into existing fairway turf. Preseeding cultivation included hollow tine core cultivation (HTC) (12.5-mm-diameter, 62.5-mm spacing, 75-mm depth) followed by three passes with a vertical mower set to a depth of $3 \mathrm{~mm}$. Seeding in the fall into a perennial ryegrass (Lolium perenne L.) stand resulted in as much as $35 \%$ creeping bentgrass over 3 years, while seeding into a mixed stand of annual bluegrass, perennial ryegrass, and kentucky bluegrass (Poapratensis L.) resulted in no more than 3\% creeping bentgrass. Gaussoin and Branham (1989) also noted a limited increase in creeping bentgrass population ( $8 \%$ ) after using vertical mowing to interseed creeping bentgrass into a mixed bentgrass/annual bluegrass stand maintained as fairway turf(13-mm mowing height). Sweeney and Danneberger (1998) studied interseeding of creeping bentgrass into existing greens of the same species. Soil preparation was a combination of HTC, vertical mowing, and topdressing. They were unable to positively identify any plants of the newly seeded cultivar.
With the exception of Roberts and Goss (1979), none of these experiments compared different preplanting soil cultivation treatments. The experiments were designed to evaluate other factors, and seed bed preparation was applied uniformly to all plots.

The traits of 'True-Putt' creeping bluegrass suggest that it has potential as a suitable turfgrass for putting greens in the Pacific Northwest. However, to be used most effectively in putting green repair, there is a need to evaluate cultural techniques such as seed bed preparation that can accelerate establishment into existing turfgrass canopies. The objective of this research was to evaluate hollow-tine cultivation, solid-tine cultivation, and vertical mowing as seed bed preparation techniques for aiding in the establishment of creeping bluegrass into existing putting green canopies.

\section{Materials and Methods}

Seeding of 'True-Putt' creeping bluegrass into existing turfgrass canopies was evaluated in three experiments at the Washington State University Puyallup Turfgrass Research Facility, located about $60 \mathrm{~km}$ southeast of Seattle, WA. The design of each of the three experiments was identical. Experimental treatments included four preseeding soil cultivation procedures plus an uncultivated control. Individual plots measured $1.2 \times 1.5 \mathrm{~m}$, and there were five replications of each treatment. The experimental design was a randomized complete block.

Two of the experiments were conducted on a research putting green where the existing turf was first killed, because it was decided that it would be difficult to evaluate germinating seed in an existing growing turf. The site was a sand-based green built in 1991, using sand conforming to U.S. GolfAassociation(USGA) particle size recommendations (USGA Green Section Staff, 1993) installed to a depth of 30 $\mathrm{cm}$ on top of the existing soil, subsequently planted with 'Putter' creeping bentgrass (Agrostis stolinifera L.). Native biotypes of Poa annua had encroached over the years to create a mixed stand. Before the experiment, mowing height was about $4.7 \mathrm{~mm}$. To kill the existing turf, the plot area was treated with glyphosate at $4 \mathrm{~kg} \cdot \mathrm{ha}^{-1}$ a.i. in March 1999. Irrigation was applied to promote germination of existing seed, and glyphosate was applied again in early May. This resulted in 100\% control of the existing turf. The remaining dead sod was left intact and all treatments and seed were applied to the existing canopy on 27 May 1999. In May 2000, an adjacent site was prepared in a similar fashion, and the study was repeated, with treatment application and seeding occurring on 2 June 2000. Following the 1999 experiment, it was thought possible to distinguish creeping bluegrass from live creeping bentgrass based on plant color. Therefore, a third experiment was established on an existing live putting green canopy, also on 2 June 2000. This sand-based green had been planted to 'L-93' creeping bentgrass in September 1998, and was mowed regularly at a height of $3.2 \mathrm{~mm}$. Because a small amount of 
Table 1. Soil cultivation treatments for experiments in existing turfgrass canopies.

\begin{tabular}{ll}
\hline Treatment name & Description \\
\hline HTC & Hollow-tine cultivation, 12.7-mm diameter tines, 50-mm spacing, depth about 75 mm, using Toro Greens Aerator (The Toro Co., Bloomington, \\
& Minn.). \\
Verticut 2X & Vertical mowing using verticutting units of triplex greens mower, 9.5-mm spacing to depth of 3.2 mm (1999) and 1.6 mm (2000). Two passes \\
& were made in perpendicular directions. \\
STC & Solid-tine cultivation with quadratines, 6.4-mm diameter tines, 40-mm spacing, depth about 50 mm, using Toro Greens Aerator \\
V+STC & (The Toro Co.). \\
Control & No pass each with verticutting reels and STC as described above. \\
\end{tabular}

annual bluegrass was already present in these plots, they were visually rated for percent cover by annual bluegrass before applying the cultivation treatments. Percent cover was variable among the plots, ranging for $2 \%$ to $15 \%$, with a mean of $5.4 \%$.

The soil cultivation treatments used to prepare the plant canopy for seeding are described in Table 1. All treatments utilized equipment that is available at most golf courses. Following cultivation, a $19 \mathrm{~N}-11.4 \mathrm{P}-4.2 \mathrm{~K}$ starter fertilizer (Scott's Contec, The Scotts Co., Marysville, Ohio) was applied uniformly to all plot areas. For the two experiments conducted on dead canopies, the $\mathrm{N}$ rate was $4.9 \mathrm{~g} \cdot \mathrm{m}^{-2}$. The $\mathrm{N}$ rate was $2.45 \mathrm{~g} \cdot \mathrm{m}^{-2}$ for the experiment conducted in live turf. 'True-Putt' creeping bluegrass was seeded at the rate of $9.8 \mathrm{~g} \cdot \mathrm{m}^{-2}$ of pure live seed using a drop spreader, applying one-half of the seed in each of two perpendicular directions. All plots, including the controls, were then lightly topdressed with sand, followed by light brushing with brooms to work sand and seed into the plant canopy. Hollow tine cultivation plots received enough sand to completely fill the aerification holes.

Plots were rated for percent cover by seedlings on a 0 to 100 scale at $2,3,4$, and 6 weeks after planting (WAP). Because differences in growth rates among plots were apparent, a visual rating of relative plant height was made once during each study, using a scale of 1 to 9 $(1=$ no plants, $9=$ tallest $)$. Data were subject to analysis of variance using the General Linear Models procedure of SAS v.8 (SAS Institute, Cary, N.C.). Experiments on the dead canopy site were analyzed for treatment and year effects and the interaction. The experiment on the living canopy site was analyzed separately using analysis of covariance, using initial $P$. annua percent cover as the covariate.

\section{Results and Discussion}

There were significant Year $\times$ treatment interaction effects for percent cover and plant height for establishment into the dead plant canopy. Weather data was not available due to weather station malfunction so it was impossible to determine the contribution of climatic factors to this interaction. The experiments were analyzed separately by year. In spring 1999, the Verticut 2X treatment resulted in significantly better establishment than all other treatments through 3 WAP, while verticutting + solid tine cultivation $(\mathrm{V}+\mathrm{STC})$ was second and HTC and solid tine cultivation (STC) were not significantly better than the control (Table 2 ). The high percent cover resulting from Verticut $2 \mathrm{X}$ within 3 WAP would be extremely important in instances where damaged areas of a green are seeded while the green is still in play. By 4 WAP, percent cover for Verticut $2 \mathrm{X}$ and $\mathrm{V}+\mathrm{STC}$ were no longer statistically different. Verticut $2 \mathrm{X}$ was still superior to HTC, STC, and the control, and V+STC was superior to STC alone at 4 WAP. Although all treatments, including the control, had reached over $90 \%$ coverage by 6 WAP, the initial quick establishment of the Verticut $2 \mathrm{X}$ treatment is an important advantage.

In Spring 2000, percent cover was more consistent between surface cultivation treatments, but the plots did not achieve cover as quickly, nor to the same extent, as in 1999. HTC resulted in higher cover at 2 WAP $(15 \%)$ compared to all other treatments, but there were no significant treatment differences after that (Table 3). Averaged over all treatments, percent cover was $35 \%, 75 \%$, and $76 \%$ at 3,4 , and 6 WAP, respectively. The lack of effectiveness of the Verticut $2 X$ treatment in 2000 compared to 1999 was probably due to differences in depth of surface penetration of the blades (1.6 and $3.2 \mathrm{~mm}$, respectively). The verticutting units were borrowed from a local golf course, and we did not discover that they were set differ-

ently until after the fact. Previous research has shown successful establishment of bentgrass into an existing green when seed was placed at a depth of about $5 \mathrm{~mm}$ (Roberts and Goss, 1979). These results, and ours, suggest that seeding depth may be critical.

The HTC treatment showed the ability of 'True-Putt' to quickly establish and spread. Seed germinated in aerification holes, spaced $50 \mathrm{~mm}$ apart. In 1999, percent cover increased from $11 \%$ at 2 WAP to $74 \%$ and $94 \%$ at 4 and 6 WAP, respectively. In 2000, percent cover increased from $15 \%$ to $79 \%$ from 2 to 4 WAP, very similar to the previous year. It was not determined whether this increase in cover was due to tiller production, stolons, or both. Regardless, the plants quickly and effectively filled spaces between aerification holes.

Following the 1999 study, it was thought that color differences between 'True-Putt' and creeping bentgrass were great enough to distinguish between these two species in a living turf canopy. In addition to the pretreatment ratings for percent cover, two postplanting ratings were taken in June, but increases in Poa coverage were small and statistically insignificant (data not shown). Coverage was rated again in November, after

Table 2. Effects of surface cultivation practices before seeding on establishment of 'True-Putt' creeping bluegrass into a dead putting green canopy, spring 1999.

\begin{tabular}{|c|c|c|c|c|c|}
\hline \multirow{2}{*}{$\begin{array}{l}\text { Surface } \\
\text { cultivation } \\
\text { treatment }\end{array}$} & \multicolumn{4}{|c|}{$\begin{array}{l}\text { Groundcover (\%) } \\
\text { at selected weeks after planting (WAP) }\end{array}$} & \multirow{2}{*}{$\begin{array}{c}\text { Plant ht } \\
\text { rating }^{\mathrm{z}} \\
3 \mathrm{WAP}\end{array}$} \\
\hline & 2 & 3 & 4 & 6 & \\
\hline Control & $7 \mathrm{c}$ & $21 \mathrm{c}$ & $70 \mathrm{bc}$ & 92 & $4.0 \mathrm{c}$ \\
\hline HTC & $11 \mathrm{c}$ & $28 \mathrm{c}$ & $74 \mathrm{bc}$ & 94 & $5.4 \mathrm{~b}$ \\
\hline STC & $8 \mathrm{c}$ & $19 \mathrm{c}$ & $65 \mathrm{c}$ & 90 & $3.2 \mathrm{c}$ \\
\hline Verticut $2 \mathrm{X}$ & $38 \mathrm{a}$ & $69 \mathrm{a}$ & $96 a$ & 99 & $6.8 \mathrm{a}$ \\
\hline $\mathrm{V}+\mathrm{STC}$ & $21 \mathrm{~b}$ & $45 \mathrm{~b}$ & $81 \mathrm{ab}$ & 95 & $5.0 \mathrm{~b}$ \\
\hline $\operatorname{LSD}^{y}(P=0.05)$ & 9 & 12 & 16 & NS & 1.0 \\
\hline CV (\%) & 38 & 25 & 16 & 7 & 17 \\
\hline
\end{tabular}

zPlant height was rated from $1=$ no plants to $9=$ tallest at 3 weeks after planting.

y Treatment means separated by a value equal to or greater than the LSD are significantly different at $P=$ 0.05 . Values within a column followed by the same letter are not significantly different.

NS Nonsignificant.

Table 3. Effects of surface cultivation practices before seeding on establishment of Poa reptans into a dead putting green canopy, Spring 2000.

\begin{tabular}{|c|c|c|c|c|c|}
\hline \multirow{2}{*}{$\begin{array}{l}\text { Surface } \\
\text { cultivation } \\
\text { treatment }\end{array}$} & \multicolumn{4}{|c|}{$\begin{array}{l}\text { Groundcover (\%) } \\
\text { at selected weeks after planting (WAP) }\end{array}$} & \multirow{2}{*}{$\begin{array}{c}\text { Plant ht } \\
\text { rating }^{2} \\
5 \text { WAP }\end{array}$} \\
\hline & 2 & 3 & 4 & $\frac{6}{6}$ & \\
\hline$\overline{\text { Control }}$ & $5 \mathrm{~b}$ & 30 & 69 & 73 & 4.2 \\
\hline HTC & $15 \mathrm{a}$ & 44 & 75 & 79 & 6.4 \\
\hline STC & $6 \mathrm{~b}$ & 35 & 76 & 75 & 4.4 \\
\hline Verticut $2 \mathrm{X}$ & $6 \mathrm{~b}$ & 31 & 79 & 80 & 4.2 \\
\hline $\mathrm{V}+\mathrm{STC}$ & $5 \mathrm{~b}$ & 33 & 74 & 75 & 4.0 \\
\hline $\operatorname{LSD}^{\mathrm{y}}(P=0.05)$ & 2 & NS & NS & NS & NS \\
\hline $\mathrm{CV}(\%)$ & 19 & 33 & 14 & 18 & 37 \\
\hline
\end{tabular}

${ }^{2}$ Plant height was rated from $1=$ no plants to $9=$ tallest at 3 weeks after planting.

y Treatment means separated by a value equal to or greater than the LSD are significantly different at $P=$ 0.05 . Values within a column followed by the same letter are not significantly different.

NSNonsignificant. 
giving the seedling 'True-Putt' time to mature, but plant species were still difficult to distinguish. Percent cover by Poa spp. ranged from $3 \%$ to $15 \%$ in individual plots (mean $9 \%$ ), but there were no statistically significant differences due to cultivation treatment. Effective establishment of 'True-Putt' may have been limited by the dense bentgrass stand. Other researchers have observed minimal success when interseeding into existing stands of live, dense, closely mowed turf(Gaussoin and Branham, 1989; Reicher and Hardebeck, 2002; Sweeney and Danneberger, 1998). Cattani (2001) found that competition from mature creeping bentgrass plants reduced plant dry weight, tiller number, and tiller weight of seedling bentgrass plants growing in $19 \mathrm{~mm}$ diameter aerification holes, resulting in low establishment success of new plants.

In an actual field situation, seeding into an existing stand would most likely take place in areas thinned by pest pressure or other environmental stresses. Such a stand would not be either entirely dead or densely populated with live grass. Plant competition in this situation would most likely lead to results intermediate to those seen in the two environments of this study. In addition, regular mowing and traffic from golfers would also influence the establishment rate. Higher mowing heights following seeding have been shown to improve seedling establishment (Roberts and Goss, 1979). The ability to restrict play and alter management practices on areas undergoing renovation could aid in seedling establishment.

\section{Conclusions}

These experiments did show the potential for 'True-Putt' creeping bluegrass to establish rapidly and effectively into existing dead turfgrass canopies. The grass filled in quickly even when seedlings emerged on $50 \mathrm{~mm}$ spacings, as was the case with HTC. Two perpendicular passes with verticutting units set to a depth of $3.2 \mathrm{~mm}$ provided the best potential for effective establishment. Rapid establishment would be critical when there is competition from other grass plants, or if the area cannot be removed from play for very long. In field applications, actual results would probably be intermediate to what was seen in the live and dead canopy experiments, depending on the health and density of the existing turf, maintenance practices, and the ability to restrict play on seeded areas.

\section{Literature Cited}

Beard, J.B. 1973. Turfgrass: Science and culture. Prentice-Hall, Englewood Cliffs, N.J.

Beard, J.B., P.E. Rieke, A.J. Turgeon, and J.M. Vargas. 1978. Annual bluegrass (Роа аппиа L.) Description, adaptation, culture and control. Res. Rep. 352. Mich. State Univ. Agr. Expt. Stn., East Lansing.

Cattani, D.J. 2001. Effect of turf competition on creeping bentgrass seedling establishment. Int. Turfgrass Soc. Res. J. 9:850-854.

Christians, N. 1998. Fundamentals of turfgrass management. Ann Arbor Press, Chelsea, Mich.

Gaussoin, R.E. and B.E. Branham. 1989. Influence of cultural factors on species dominance in a mixed stand of annual bluegrass/creeping bentgrass. Crop Sci. 29:480-484.

Reicher, Z.J. and G.A. Hardebeck. 2002. Overseeding strategies for converting golf course fairways to creeping bentgrass. HortScience 37(3):508-510.

Roberts, J.M. and R.L. Goss. 1979. Overseeding methods following endothall or endothall/bensulide treatments. J. Sports Turf Res. Inst. 55:99-106.

Sweeney, P. and K. Danneberger. 1998. Introducing a new creeping bentgrass cultivar through interseeding: Does it work? U.S. Golf Assn. Green Sect. Record 36(5).

U.S. Golf Aassociation Green Section Staff. 1993. USGA recommendations for a method of putting green construction: the 1993 revision. U.S. Golf Assn. Green Sect. Record 31(2):1-3.

White, D.B. and T.D. Carson.1999. Poa annua reptans-creeping bluegrass. On Course 52:9. 